\title{
IN VITRO STUDY OF APOPTOSIS INDUCTION BY L-ASPARAGINASE OF ASPERGILLUS FUMIGATUS (ASPF-6) ON HUMAN LEUKEMIA CELL LINES
}

\author{
VIPINA R*, VIJAYA CHITRA A
}

Department of Microbiology, See Narayana Guru College, Coimbatore, Tamil Nadu, India. Email:vipinaprasad@gmail.com

Received: 24 January 2019, Revised and Accepted: 23 May 2019

\section{ABSTRACT}

Objective: L-Asparaginase is a relatively widespread enzyme used in the lymphoblastic leukemia chemotherapy. In the present investigation, we report new potential fungal L-asparaginase producer Aspergillus fumigatus from Kadalundi mangrove forest, Kerala. The aim of the present investigation was to evaluate the concentration-dependent cytotoxicity and apoptosis-inducing the effect of extracted enzyme and its ability to induce apoptosis against human leukemia cell lines-HL-60.

Methods: The fungal strain was isolated by serial dilution method from rhizosphere soil of mangrove forest. The isolated enzyme purified by $80 \%$ ammonium sulfate precipitation, dialysis, and ion exchange chromatography. To determine cytotoxicity and level of apoptosis, three different tests were performed: (3-(4,5-dimethylthiazol-2-yl)-2,5-diphenyltetrazolium bromide, JC-1 flow cytometry, and Annexin $\mathrm{V} /$ propidium iodide (PI) flow cytometric DNA fragmentation. The test compound efficiency compared with positive drug doxorubicin against HL-60 cell lines.

Results: The test compound exhibited a concentration-dependent cytotoxic effect on proliferation of HL-60 cell lines (IC-50 12.39 U) with a different level of apoptosis induction (LR-11.3\%).

Conclusion: A. fumigatus derived L-asparaginase may be clinically useful and results in better utilization for limited fungal-derived drug resources and improve financial feasibility as a therapeutic option for human leukemia.

Keywords: L-asparaginase, A. fumigatus, 3-(4,5-dimethyl thiazol-2-)-2,5-diphenyl tetrazolium bromide assay, Annexin V/PI and JC-1 Flurocytometry.

(C) 2019 The Authors. Published by Innovare Academic Sciences Pvt Ltd. This is an open access article under the CC BY license (http://creativecommons. org/licenses/by/4. 0/) DOI: http://dx.doi.org/10.22159/ajpcr.2019.v12i7.32158

\section{INTRODUCTION}

L-Asparaginase (L-asparagine amidohydrolase, EC 3.5.1.1) is an enzyme present in many animal tissue, bacteria, and plants and serum of certain rodents, but not in mankind. L-Asparaginase hydrolyzes the amidase bond in L-asparagine to L-aspartic acid and ammonia. L-asparagine is required for both normal and cancer cell. Normal cell acquires L-asparagine through diet or synthesized using asparagine synthetase by protein synthesis. Tumor cell depends on the absorption of L-asparagine from the blood. When L-asparaginase was administrated, as a therapeutic agent, its catalytic activity results in depletion of L-asparagine into ammonia and aspartic acid. The enzyme widely used in cancer therapeutics and has shown effective results for acute lymphoblastic, leukemia treatment of children [1].

L-asparaginase derived from fungi has been less studied than bacteria. Fungi have able to produce and secrete this enzyme [2]. Filamentous fungi belonging to the genera Aspergillus, Penicillium, Fusarium, and some yeast species can produce this enzyme [3]. Based on the reduction of 3-(4,5-dimethyl thiazol-2-)-2,5-diphenyl tetrazolium bromide (MTT) to a formazan product by living but not by dead cell has been used for large scale cytotoxic studies [4]. Anti-proliferative effect of recombinant L-asparaginase from thermotolerant $E$-coli strain was reported on leukemic cell line like and HL-60 [5,6].

In the present study, anticancer activity of L-asparaginase from Aspergillus fumigatus was observed on leukemia cell lines, HL-60. The mitochondrial potential of the treated cell was indicated using JC-1 flow cytometry and apoptosis by Annexin V/propidium iodide (PI) flurocytometry modern techniques.

\section{MATERIALS AND METHODS}

\section{Sample collection and isolation}

The soil sample was collected from mangrove rhizosphere soil. The dilution plate method was employed for the isolation of fungal strains. The isolated microorganisms were maintained on Czapek-Dox medium (Glucose-2 gm, L-asparagine-10 gm, $\mathrm{KH}_{2} \mathrm{PO}_{4}-1.52 \mathrm{gm}, \mathrm{KCl}-0.52 \mathrm{gm}$, $\mathrm{MgSO}_{4} \cdot 7 \mathrm{H}_{2} \mathrm{O}-0.52 \mathrm{gm}, \mathrm{CuNO}_{3} \cdot 3 \mathrm{H}_{2} \mathrm{O}$-trace, $\mathrm{ZnSO}_{4} .7 \mathrm{H}_{2} \mathrm{O}$-trace, and $\mathrm{FeSO}_{4}$ $7 \mathrm{H}_{2} \mathrm{O}$-trace/l) at $\mathrm{pH} 6.2$ and $0.09 \%$ phenol red as an indicator to the media [7].

\section{Screening of L-asparaginase producing fungi}

The isolated fungi were subjected to rapid screening for L-asparaginase production by plate assay [8] in Czapek-Dox agar. Control plates were of modified Czapek-Dox medium containing $\mathrm{NaNO}_{3}$ instead of $\mathrm{L}$-asparagine as nitrogen source and phenol dye as an indicator. The isolates that showed pink-zone around the colonies after incubation at $30^{\circ} \mathrm{C}$ for $48 \mathrm{~h}$ were selected for determination of enzyme activity.

\section{L-asparaginase production by submerged fermentation}

The cultures were inoculated in Erlenmeyer flask containing $50 \mathrm{ml}$ of modified Czapek-Dox medium. The flask incubated at $30^{\circ} \mathrm{C}$ at 150 rpm for 8 days. The enzymatic activity was measured at a subsequent interval. Uninoculated media serve as a control. The cultures were harvested by centrifugation at $1800 \mathrm{rpm}$ for $15 \mathrm{~min}$ at a refrigerator condition $\left(4^{\circ} \mathrm{C}\right)$, and the clear supernatant was used as the crude enzyme extract to determine the enzyme activity and protein assay.

\section{L-asparaginase assay}

The rate of hydrolysis of L-asparaginase was determined by measuring the released ammonia using Nessler's reagents [9]. The reaction was 
started by adding $100 \mu \mathrm{l}$ enzyme extracts into $200 \mu \mathrm{l}$ of $0.05 \mathrm{M}$ Tris $\mathrm{HCl}$ Buffer (pH 8.6) and $1.7 \mathrm{ml}$ of $0.01 \mathrm{M}$ asparagine, incubated for $10 \mathrm{~min}$ at $37^{\circ} \mathrm{C}$. The reaction was stopped by addition of $500 \mu \mathrm{l}$ of $1.5 \mathrm{M}$ TCA. After centrifugation at $10,000 \mathrm{rpm}$ at $4^{\circ} \mathrm{C}, 0.5 \mathrm{ml}$ of the culture supernatant was diluted to $7 \mathrm{ml}$ with distilled water and followed by addition of 1 $\mathrm{ml}$ of Nessler's reagent. Allowed $10 \mathrm{~min}$ for color reaction and OD was checked at $425 \mathrm{~nm}$ with a spectrophotometer. The ammonia liberated was entrapped in a curve derived with ammonium sulfate as a standard curve. $1 \mathrm{U}$ of L-asparaginase was defined as the amount of enzyme which liberates $1 \mu \mathrm{M}$ of ammonia per minute under the assay condition at $\mathrm{pH} 8.6$ at $37^{\circ} \mathrm{C}$.

\section{Purification of enzyme extract}

The enzyme was purified using ammonium sulfate precipitation, dialysis and applied to ion-exchange chromatography through sulfopropylsepharose and carboxy methyl-sepharose. The purified extract was subjected to sodium dodecyl sulfate-polyacrylamide gel electrophoresis (SDS-PAGE). Protein content was determined by Lowry's method using bovine serum albumin as the standard [10].

\section{Antitumor activity of l-asparaginase on HL-60 cell line Tumor cell lines}

HL-60 (Human leukocytes) cell lines were collected from the National Center for Cell Science, Pune, India. L-asparaginase is an anticancer enzyme widely used against leukemia cancer cell. HL-60 cell line is floating and grows in suspension. The cells were maintained in RPMI1640 [11] supplemented with $10 \%$ fetal bovine serum, streptomycin $(1 \%)$, and penicillin $(1 \%)$ which were added to inhibit bacterial contamination [12]. The cells were kept in a $\mathrm{CO}_{2}$ incubator at $37^{\circ} \mathrm{C}$.

\section{Experimental design}

The cells were dissociated by washing with PBS $(\times 1)$. Extracellular matrix was removed using Trypsin and it is continued for 2-4 mine in $\mathrm{CO}_{2}$ incubator. After trypsinization cells were suspended in fresh serum to neutralize the trypsin [13]. The solution subjected to centrifugation at 25,000 rpm/4 min and the pellet was collected.

\section{Cell counting}

The cells are counted using hemocytometer. The cell suspension was mixed with dye trypan blue solution in the ratio of 1:1 $[14,15]$.

\section{Calculation}

Total number of Viable cell $=\mathrm{A} \times \mathrm{B} \times \mathrm{C} \times 10^{4}$

Total number of dead cells $=\mathrm{A} \times \mathrm{B} \times \mathrm{D} \times 10^{4}$

Total cell count $=$ Viable cell count + dead cell count

$\%$ of viability $=\frac{\text { Viable cell count } \times 100}{\text { Total cell count }}$

Where,

$\mathrm{A}=$ Volume of cells

$\mathrm{B}=$ Dilution factor in trypan blue

$\mathrm{C}=$ Mean number of unstained cells

$\mathrm{D}=$ Mean number of dead or stained cells

\section{MTT assay}

MTT assay is a colorimetric method for sensitive quantification of viable cells in proliferation and cytotoxicity assay [16,17]. It is based on reduction of the yellow colored water-soluble tetrazolium dye MTT to formazan crystals that are insoluble in cell culture media. The conversion brought about by mitochondrial lactate dehydrogenase produced by live cells reduces MTT to insoluble formazan crystals, which on dissolution into an appropriate solvent exhibits purple color, the intensity directly proportional to number of viable cells and measured spectrophotometrically at $570 \mathrm{~nm}[18,19]$.
Assay controls

i. Medium control (medium without cells)

ii. Negative control (medium with cells but without the experimental drug/compound)

iii. Positive control (medium with cells and with $10 \mu \mathrm{M}$ of CPT)

Same media were used in control as well as test wells $[20,22]$.

\section{Procedure for determining cell cytotoxicity}

Two hundred microliters cell suspension at a required cell density of 20,000 cells per well was added in 96 well plates and incubated for $12 \mathrm{~h}$. Test agent L-asparaginase was added at a concentration of 1,10 , 15 , and $20 \mu \mathrm{g} / \mathrm{ml}$, respectively. The plates were incubated at $37^{\circ} \mathrm{C}$ in $\mathrm{CO}_{2}$ atmosphere for about $48 \mathrm{~h}$. Spent media were trashed out, and MTT reagent was added to a final concentration of $0.05 \mathrm{mg} / \mathrm{ml}$ of total volume. The plate was wrapped with aluminum foil to avoid exposure to light. The plate was incubated for $3 \mathrm{~h}$ and MTT reagent was removed and to it $100 \mu \mathrm{l}$ of solubilization solution was added. The plate was subjected to stirring in a gyratory shaker, and absorbance was read on a spectrophotometer at $570 \mathrm{~nm}[24,26]$.

Determination of $I C_{50}$ value

$\mathrm{IC}_{50}$ was a quantitative measure which indicates how much of a particular drug or other substance needed to inhibit a given biological process by half. It is the half maximal (50\%) inhibitory concentration of a substance $[27,29]$. The percentage of inhibition calculated using the formula.

Mean OD of untreated cell (control)-Mean OD of treated cell Mean OD of treated cell 100

The graph can be plotted with the percentage of inhibition on Y-axis and the concentration of drug on X-axis and $\mathrm{IC}_{50}$ concentration was determined.

Mitochondrial membrane potential assay by JC-1flow cytometry method The effect of L-asparaginase on mitochondrial membrane-potential in HL-60 was evaluated using JC-1 dye [30,31]. In normal mitochondria, JC-1 forms aggregate and emit red fluorescence. The dead population with low mitochondrial membrane potential dye remains in a monomeric form which emits green fluorescence. 96-well plate was seeded with the cell at a density of $3 \times 10^{5}$ cells $/ 1 \mathrm{ml}$ and incubated in $\mathrm{CO}_{2}$ incubator at $37^{\circ} \mathrm{C}$ for $24 \mathrm{~h}$, keeping first well as blank, and second well as a positive control (doxorubicin). The cell treated with $20 \mu \mathrm{g} /$ $\mathrm{ml}$ of L-asparaginase and incubated, harvesting and centrifuged at $300 \times \mathrm{g}$ at $25^{\circ} \mathrm{C}$ washed with PBS $[32,33]$. JC- 1 dye at a concentration of $0.5 \mathrm{ml}$ was added and vortexed to disrupt cell to cell clumping. After incubation at $37^{\circ} \mathrm{C}$ in $\mathrm{CO}_{2}$ incubator for $10-15 \mathrm{~min}$, cells were washed 2 times with $1 \times$ assay buffer and centrifuged at $400 \times$ g for 5 min and discarded the supernatant. The cell pellet suspended in $1 \times$ assay buffer and analyzed by flow cytometry $[34,35]$.

\section{Detection of apoptosis}

Early apoptotic events were detected using Annexin V/PI fluoro cytometric study $[36,37]$. The cells were cultured in a 6 well plate at a density of $3 \times 10^{5}$ cells $/ 1 \mathrm{~mL}$ and incubated in a $\mathrm{CO}_{2}$ incubator overnight at $30^{\circ} \mathrm{C}$ for $24 \mathrm{~h}$. The cells were then treated with experimental compound L-asparaginase and positive control doxorubicin, in $1 \mathrm{~mL}$ RPMI medium and again incubated for $24 \mathrm{~h}$. The cells were transferred to $12 \times 75 \mathrm{~mm}$ polystyrene tubes and centrifuged at $300 \times \mathrm{g}$ at $25^{\circ} \mathrm{C}$ for $5 \mathrm{~min}$, and the pellet was collected. The cells were then washed twice with PBS and treated with $5 \mu \mathrm{l}$ of FITC Annexin V [38]. The suspension was vortexed and incubated for $15 \mathrm{~min}$ at room temperature in the dark. Five microliters of PI and $400 \mu$ of $1 \times$ binding buffer was added to each tube and gently vortexed buffer to each tube and analyzed immediately by flow cytometry after addition of PI. 


\section{RESULTS}

Isolation and screening of microorganisms

A total of 18 fungal cultures isolated from rhizosphere mangrove rhizosphere soil. The potential strain was selected on the basis of the pink zone around the colony by plate assay method. The strain that showed complete color change was selected for secondary screening. The maximum enzyme activity of $32.8 \mu / \mathrm{ml}$ was observed in secondary screening.

\section{Purification of enzyme extract}

The enzyme was purified 2.6-fold with a recovery of 5.6\% and a specific activity of $23.96 \mathrm{U} / \mathrm{mg}$ of protein. The concentrated-active fraction was further purified by CM-Sepharose column chromatography. After the final purification, the enzyme was purified three-fold with a recovery of $2.7 \%$ and specific activity of $27.25 \mathrm{U} / \mathrm{mg}$ of protein. The purified $\mathrm{L}$-asparaginase appeared as a single protein band in SDS-PAGE and molecular weight of $56 \mathrm{KDa}$.

\section{In vitro cytotoxic activity}

The results of the in vitro cytotoxicity using MTT assay are depicted in Fig. 1. The decrease in cell count was observed with increase in the concentration of the enzyme extracts. In vitro exposures of HL-60 cells with various concentration of L-asparaginase significantly suppressed HL-60 cancer cell growth in a dose-dependent manner. The maximum inhibition of HL-60 due to exposure to L-asparaginase was found at $20 \mu \mathrm{g} / \mathrm{ml}$ of the enzyme extracts and $73.66 \%$ inhibition in viability

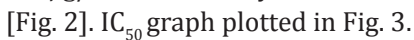

Mitochondrial membrane potential study of the compound L-asparaginase against HL-60 cell line

JC-1 expression study of the test compound (L-asparaginase) against HL-60 cell line is represented in Table 1 and Fig. 4. Given test compound (L-asparaginase) showed significant reduction of mitochondrial membrane integrity against the HL-60 by showing the shift of cells from upper right (UR) quadrant-red (FL 2) to lower right (LR) quadrantGreen (FL 1) represented in Fig. 5.

Apoptosis study of L-asparaginase treated HL-60 cell lines In the apoptotic cell, loss of plasma membrane asymmetry is one of the earliest features of apoptosis. In the apoptotic cell, the membrane phospholipid phosphatidylserine (PS) is translocate from the inner membrane to outer and exposed to the outer cellular environment. 36$36 \mathrm{kDa}$ Annexin $\mathrm{V}$ is a $\mathrm{Ca}^{2+}$ dependent phospholipid-binding protein with

Table 1: The percentage of cells of arrested in different stages of apoptosis in the untreated, standard, and test compound, namely L-asparaginase treated HL 60 cells and overlay of the results plotted in bar graph

\begin{tabular}{lll}
\hline Quadrant & UR & LR \\
\hline Label & FL1-JC1 & FL2-JC1 \\
Untreated HL 60 cells & 99.96 & 0 \\
STD & 33.13 & 66.85 \\
Test compound-1 (L-asparaginase) & 52.04 & 47.82 \\
\hline
\end{tabular}

UR: Upper right, LR: Lower right, STD: Standard and test compound,

FL1: Fluorescence channel1, HL: Human acute promyelocytic leukemia cell line,

JC-1: 5,5',6,6' tetrachloro-1,1',3,3'-tetra ethylbenzimidazol carbocyanineiodide

Table 2: Details of drug treatment

\begin{tabular}{llll}
\hline S.No & Test compounds & Cell line & $\begin{array}{l}\text { Concentration } \\
\text { treated to cells }\end{array}$ \\
\hline 1 & Untreated & HL 60 & No treatment \\
2 & STD (doxorubicin) & HL 60 & $15 \mu \mathrm{g} / \mathrm{ml}$ \\
3 & Test-1 (L-asparaginase) & HL 60 & 12.39 unit \\
\hline
\end{tabular}

STD: Standard and test compound, HL: Human acute promyelocytic leukemia cell line high affinity for phospholipid PS and binds to exposed PS on the apoptotic cell surface. Annexin V can be conjugated to fluorochrome which retains its high affinity for PS and serves as a sensitive probe for flow-cytometric analysis of cells undergoing apoptosis. In untreated samples, the majority of cells were viable (96.2\%) and nonapoptotic (Annexin V-PI'). However, when cells were treated with positive drug doxorubicin with $15 \mu \mathrm{M}$ [Table 2] for $4 \mathrm{~h}, 27.98 \%$ of Annexin V-PI cells were observed. Test compound L-asparaginase exhibited 50.96 of Annexin V-PI: There was an increase in early apoptotic cell populations (AnnexinV+PI-) from untreated to treated cells such as $73 \%$ to $9.83 \%$ in doxorubicin positive drug and $11.3 \%$ in test compound L-asparaginase [Table 3].

HL-60 cell lines treated with standard drug Doxorubicin and test compound Lasparaginase is represented in Fig. 6. Fig. 6 shows proof-of-principle data from the Hl-60 untreated, treated with the standard drug, and test

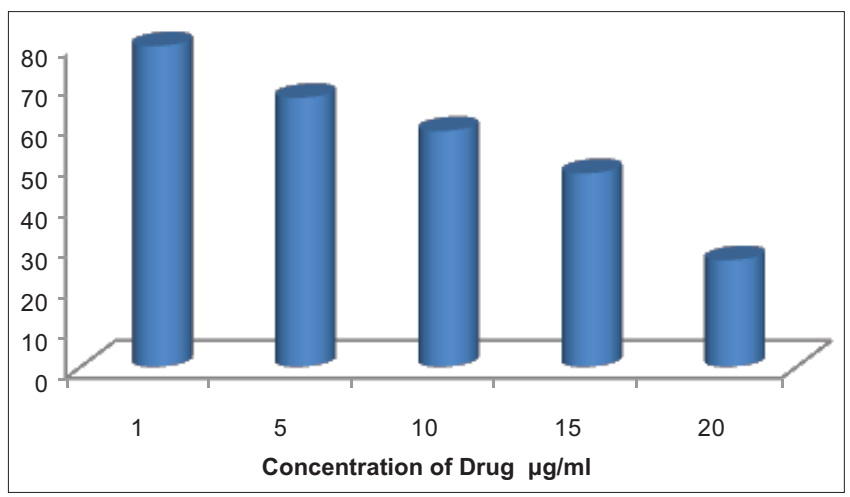

Fig. 1: Percentage of viability

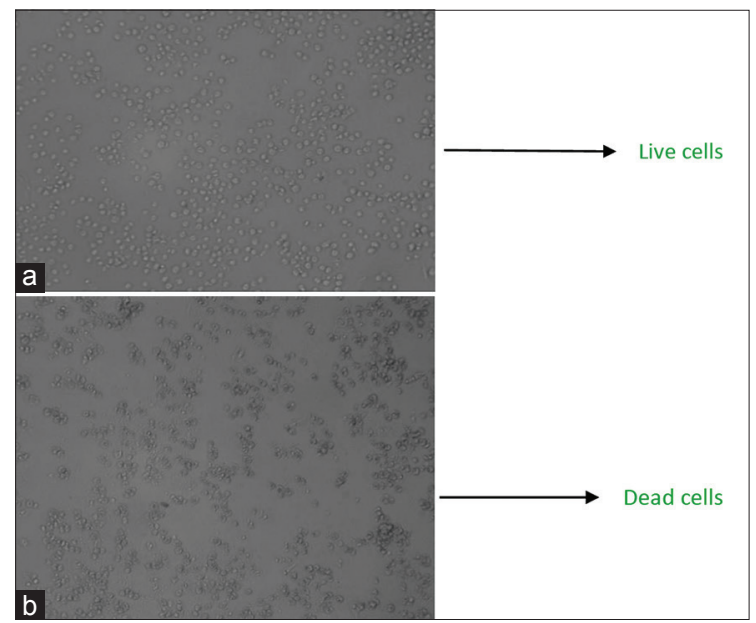

Fig. 2: HL-60 cell images after treatment. (a) Control. (b) L-asparaginase at $20 \mu \mathrm{g} / \mathrm{ml}$

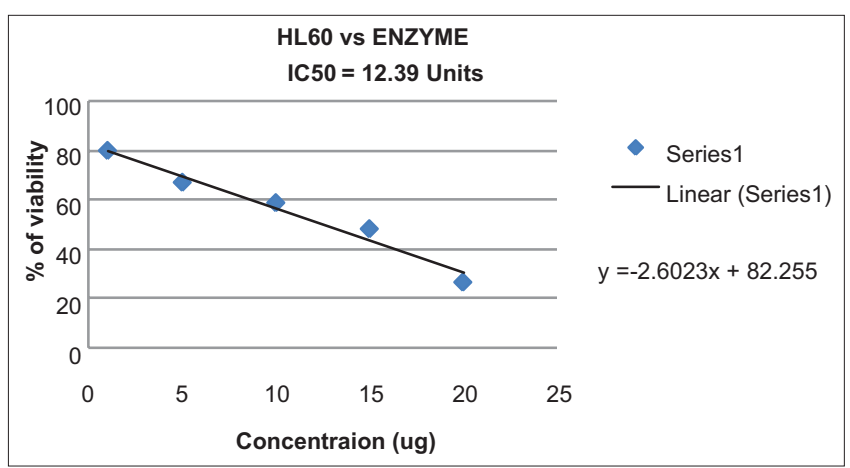

Fig.3: IC $_{50}$ graph 


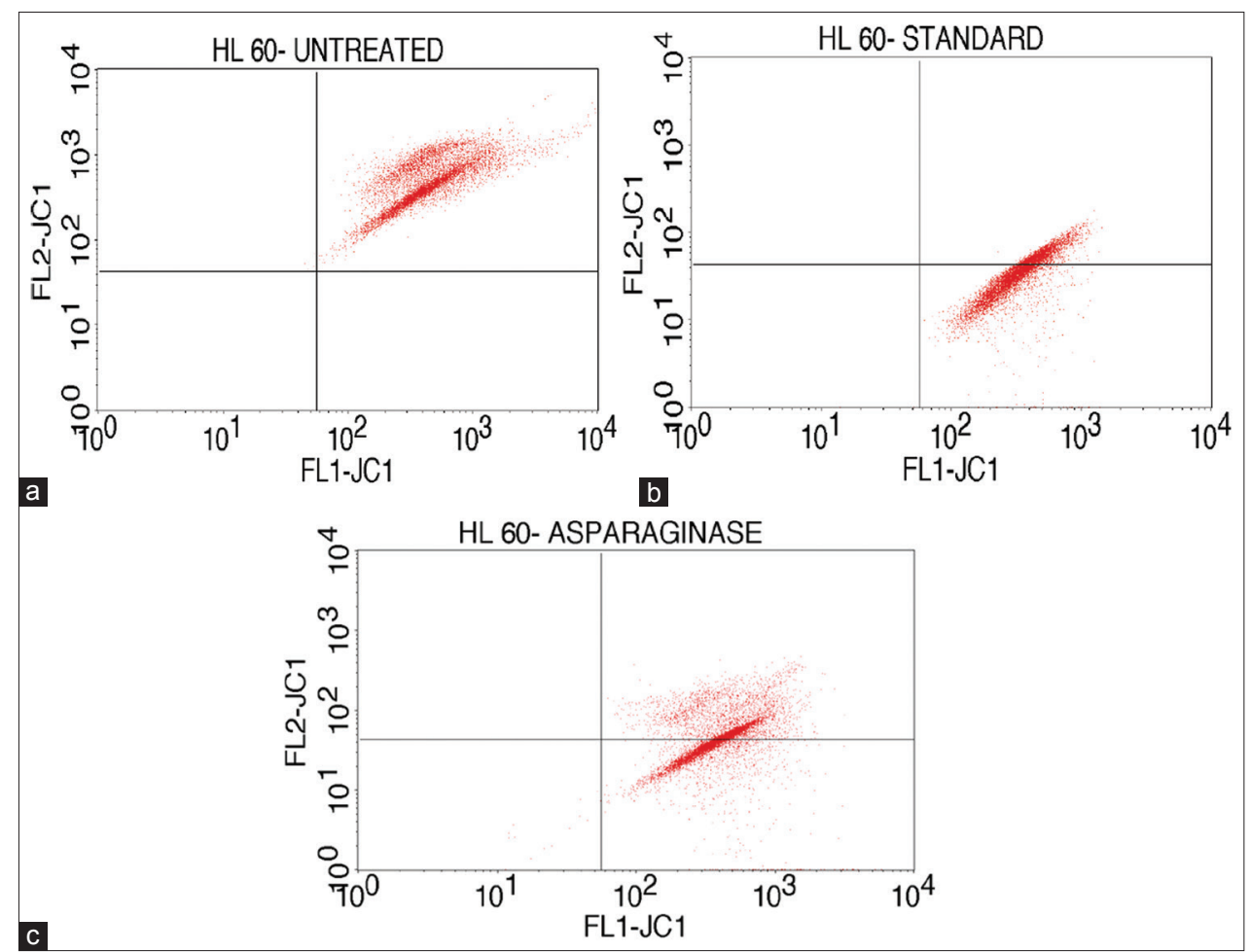

Fig. 4: Mitochondrial membrane potential study of the test compound-1 (L-asparaginase) against HL 60 cell line: JC1 expression study of test compound (L-asparaginase) on HL 60 cells using BD FACS caliber, Cell Quest Pro Software (Version: 6.0). Quadrants showing the expression of JC1 stain in the given untreated HL 60 Cells (a), standard drug (Doxorubicin) (b) and L-asparaginase treated HL 60 cells (c)

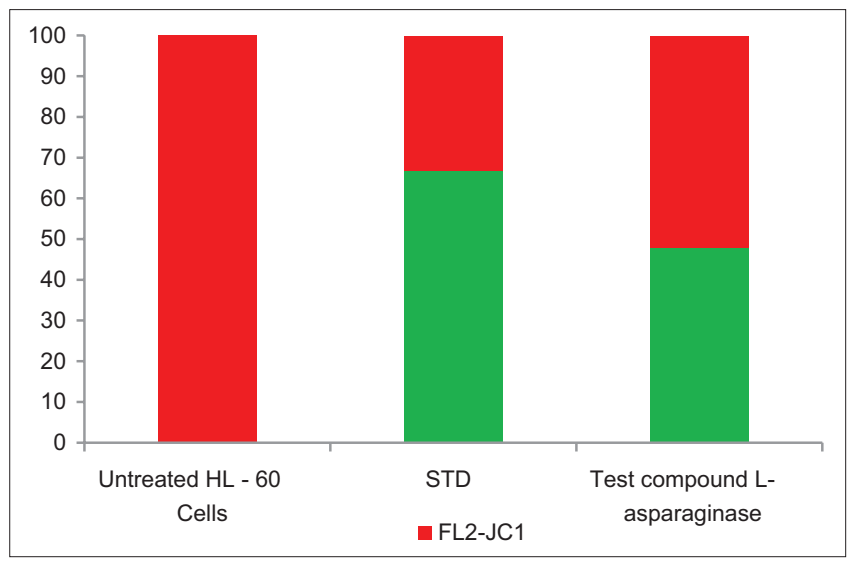

Fig. 5: The percentage of healthy and unhealthy cell $s$ after treatment

compound Lasparaginase as Annexin V FITC versus PI counter plots with quadrant gates showing four populations. In the untreated control sample, the majority of $(96.2 \%)$ cells were viable and non-apoptotic, and standard drug-treated cell line (Fig. 7a,b) and test compound L-asparaginase treated cells Fig. 7c shows decrease in the Annexin V-PI-populations and increase in cells undergoing early apoptotic (Annexin $\mathrm{V}^{+} \mathrm{PI}$ )

Lower left quadrant population (LL) represents the viable cells. About $96.20 \%, 27.98 \%$, and $50.96 \%$ of cells were found in untreated, standard, and test compound namely L-asparaginase, respectively, in the LL quadrant. Upper left (UL) quadrant represents cells debris or necrotic cells. About $2.24 \%, 0.43 \%$, and $5.75 \%$ of cells were found in untreated, standard, and test compound L-asparaginase, respectively, in the UL quadrant. UR quadrant represents late apoptotic cells. About $0.82 \%$, $61.75 \%$, and $31.99 \%$ of cells were found in untreated, standard, and test

\begin{tabular}{|ll|}
\hline UL & UR \\
Percentage of necrotic cells & Percentage late apoptotic cells \\
\hline LL & LR \\
Percentage viable cells & $\begin{array}{l}\text { Percentage of early apoptotic } \\
\text { cells }\end{array}$ \\
\hline UR: Upper right, LR: Lower right, UL: Upper left, LL: Lower left \\
\hline
\end{tabular}

Fig. 6: Meaning of the quadrant layout in apoptosis study

compound, namely L-asparaginase, respectively, in the UR quadrant. LR quadrant represents early apoptotic cells. About $0.74 \%, 9.84 \%$, and $11.30 \%$ of cells were found in untreated, standard, and test compound, namely L-asparaginase, respectively, in the LR quadrant (Fig.8).

\section{DISCUSSION}

The first reviews on L-asparaginase demonstrate anti-leukemic activity, but progress has been made in the therapeutic practical that combined L-asparaginase with chemotherapeutic drug [12]. The current investigation is the first report in the isolation of L-asparaginase from A. fumigatus species. Antiproliferative effect of $\mathrm{L}$-asparaginase from A. fumigatus was evaluated after $48 \mathrm{~h}$ of incubation on HL-60 cell lines. The L-asparaginase caused $74 \%$ reduction in cell viability after $48 \mathrm{~h}$ of treatment. Efficacy of the antiproliferative effect of L-asparaginase from Streptomyces enissocaesilis on different cell lines at a concentration of $5.0 \mathrm{IU} / \mathrm{mL}$ showed cell inhibition such as $82.3 \%$ on MCF-7, $71.7 \%$ on MDA-MB4355 (Breast metastatic cancer), $64.2 \%$ and $60 \%$ in HeLa cell lines and Human small lung cancer cell lines H69PR, and in 52.1\% in COLO205 cell lines [21]. L-asparaginase from Enterobactor clocae against human myeloid Leukemia cell line, MDA-MB-2311 at the concentration of 2,5,10.and $15 \mathrm{IU} / \mathrm{Ml}$ [23] , showed IC50 value 3.1, 7.1 and $11.8 \mathrm{IU} \mathrm{ml}^{1}$. L-asparaginase from Salinococcus spp. showed cytotoxicity against HL-60 cell lines $[25,28]$. In this study, we attempted to understand the effect of 
Table 3: The percentage of cells of arrested in different stages of apoptosis in the untreated, standard, and test compound Lasparaginase

\begin{tabular}{lllll}
\hline Quadrant & $\begin{array}{l}\text { Percentage of } \\
\text { necrotic cells }\end{array}$ & $\begin{array}{l}\text { Percentage of late } \\
\text { apoptotic cells }\end{array}$ & $\begin{array}{l}\text { Percentage of } \\
\text { viable cells }\end{array}$ & $\begin{array}{l}\text { Percentage of early } \\
\text { apoptotic cells }\end{array}$ \\
\hline Label & UL & UR & LL & LR \\
Untreated cells & 2.24 & 0.82 & 96.2 & 0.74 \\
STD (doxorubicin) & 0.43 & 61.75 & 27.98 & 9.84 \\
Test compound & 5.75 & 31.99 & 50.96 & 11.3 \\
L-asparaginase & & & & \\
\hline
\end{tabular}

STD: Standard and test compound, UR: Upper right, LR: Lower right, UL: Upper left, LL: Lower left

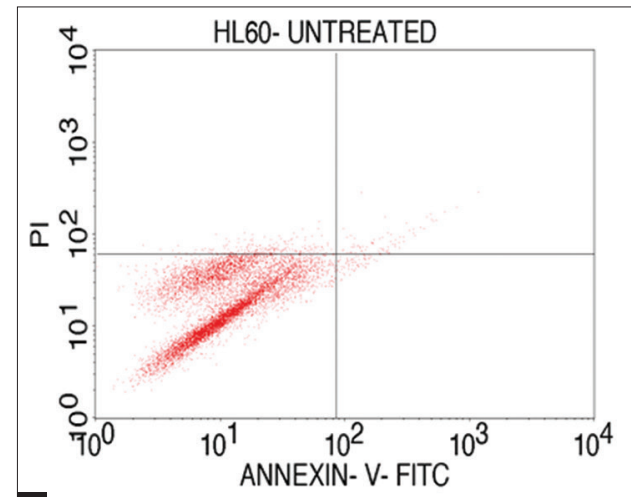

a

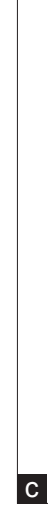

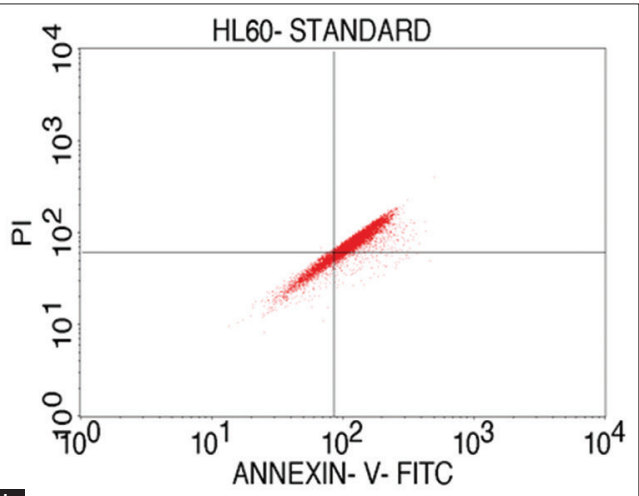

b

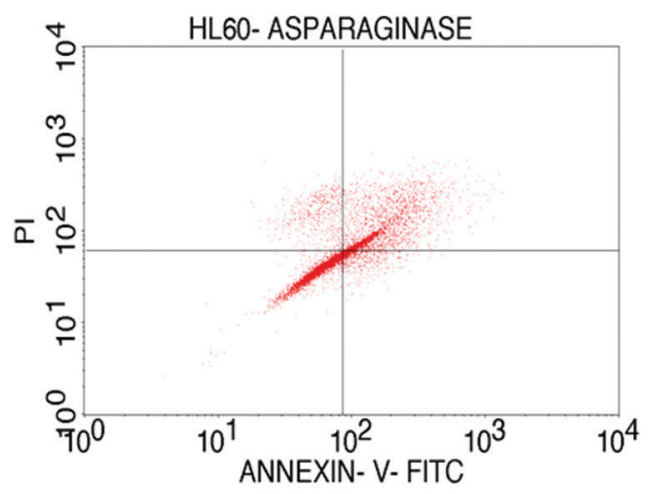

Fig. 7: Annexin V-PI expression study of test compound (Asparaginase) on HL 60 cells using BD FACSCalibur, Cell Quest Pro Software (Version: 6.0). Quadrants showing the expression of given untreated HL 60 Cells (a) and standard drug (Doxorubicin-15uM) treated HL 60 cells (b) and test compound-1 (L-asparaginase) treated HL 60 cells against the Annexin V-FITC and propidium iodide stain

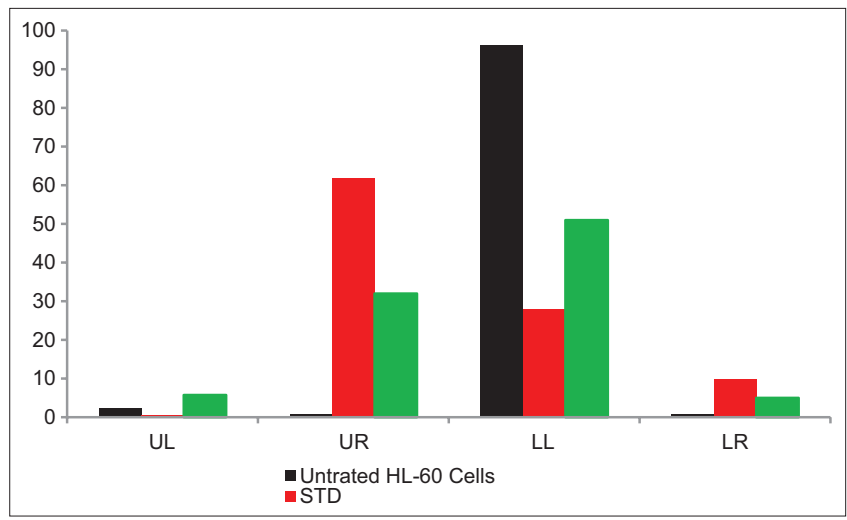

Fig. 8: The percentage of apoptotic cells gated in the different samples

L-asparaginase alone on mitochondrial membrane permeability in HL-60 cells, and there is an increased loss of mitochondrial membrane potential and likely of inducing apoptosis in HL-60 cell lines, after $48 \mathrm{~h}$ of treatment.

\section{CONCLUSION}

The treatment of cancer is largely based on the use of the chemotherapeutic drug that affects the viability and growth rate of tumor cells. Extraction and purification of natural product L-asparaginase from fungal species have attracted much attention, due to the cost-effective and eco-friendly in nature. Although there are many therapeutic bacterial derived L-asparaginase present in the market, recent studied pointed out that asparaginase from fungal species might be more efficient and also exhibited fewer side effects. Our study demonstrates that L-asparaginase isolated from A. fumigatus ASPF- 6 has enhanced anti-proliferative and exhibited a higher degree of early apoptosis, compare to necrosis or late apoptosis on the human leukemia cell line, HL-60. The needs of new sources for therapeutic enzyme have much attention in both medicine and biotechnology.

\section{ACKNOWLEDGMENTS}

We would like to thank Unibiosis Research Lab Pvt., Ltd., Kochi, and NCCAE Centre in Bharathidasan University for providing the lab facility and support to conduct the present study. 


\section{AUTHORS' CONTRIBUTIONS}

Vipina and Vijaya Chitra designed and performed the experiment, derived the models, and analyzed the data. Vipina performed the experiment under the guidance and supervision of Vijaya Chitra. Vipina drafted the manuscript and designed the figures. Vijaya Chitra aided in interpreting the results and worked on the manuscript. Two authors discussed the results and commented on the manuscript.

\section{CONFLICTS OF INTEREST STATEMENT}

Authors declared that there is no competing interest between them.

\section{REFERENCES}

1. Marshall SA, Lazar GA, Chirino AJ, Desjarlais JR. Rational design and engineering of therapeutic proteins. Drug Discov Today 2003;8:212-21.

2. Sarquis MI, Basker GO, Renganathan S. Design of experiments and ANN linked genetic algorithem for modeling and optimization of 1-asparaginase production by Aspergillus terreus, MTCC 1782. Res J Math Stat 2009;1:55

3. Sarquis MI, Oliveira EM, Santos AS, Costa GL. Production of 1-asparaginase by filamentous fungi. Mem Inst Oswaldo Cruz 2004;99:489-92.

4. Mosmann T. Rapid colorimetric assay for cellular growth and survival: Application to proliferation and cytotoxicity assays. J Immunol Methods 1983;65:55-63.

5. Muharram MM, Abdulhamd AT, Mounir MS. Recombinant expression, purification of 1-asparaginase -11 from thermotolerant E. coli strain and evaluation of its antiproliferative activity. Afr J Microbiol 2014;8:1610-9.

6. Loureiro C. Purification and biochemical characterisation of native and pegglated form of 1-asparaginase from Aspergillus terreus and evaluation of its antiproliferative activity. J Adv Microbiol 2012;2:138-45.

7. Prakasham RS, Hymavathi M, Subba Rao Ch, Arepalli SK, Venkateswara Rao J, Kennady PK, et al. Evaluation of antineoplastic activity of extracellular asparaginase produced by isolated Bacillus circulans. Appl Biochem Biotechnol 2010;160:72-80.

8. Gulati R, Saxena RK, Gupta R. A rapid plate assay for screening of 1-asparaginase producing microorganism. J Appl Microbiol 1997;24:23-6.

9. Kafkewitz D, Goodman D. L-asparaginase production by the rumen anaerobe Vibrio succinogenes. Appl Microbiol 1974;27:206-9.

10. Lowry OH, Rosebrough NJ, Farr AL, Randall RJ. Protein measurement with the folin phenol reagent. J Biol Chem 1951;193:265-75.

11. Pallaga U, Rao CS, Ragulapati SB. Studies on 1-aspraginase production by using Staphylococcus capitis. J Chem Biol Phys Sci 2013;3:201-9.

12. Loureiro CB, Borges KS, Andrade AF, Tom LG. Purification and biochemical characterization of native and pegylated form of 1-asparaginase from Aspergillus terreus and evaluation of its antiproliferative activity. J Adv Microbiol 2012;2:138-45.

13. Rajesh MJ, Rajesh L, Satyaveni VV, Thirumurugan G, Sivasubramanian R. Effect of inducers and physical parameters on the production of 1-asparaginase using Aspergillus terreus. J Bioprocess Biotech 2011;1:4-8.

14. Amena S, Vishalakshi N, Prabhakar M, Dayanand A, Lingappa K. Production, purification and characterization of 1-asparaginase from Streptomyces gulbargensis. Braz J Microbiol 2010;41:173-8.

15. Wade HE, Robinson HK, Philips BW. Asparaginase and glutaminase activities of bacteria. Journal of general microbiology 1971; 299-312.

16. Dhevangi P, Poorani E. Isolation and characterization of 1-asparaginase from marine Actinomycetes. Int J Biotechnol 2006;5:48-52.

17. E-Moharam M, Gamal-Eldeen AM, El-Sayed ST. Production, immobilization and anti tumor activity of 1-asparaginase of Bacillus sp R36. J Am Sci 2010;6:72-5.

18. Mohammed A, Mazini AL. L-asparaginase activity by various bacteria. J Missan Res 2008;4:12-5.

19. Mishra A. Production of 1-asparaginase, an anticancer agent, from Aspergillus niger using agricultural waste in solid state fermentation. $\mathrm{J}$ Appl Biochem Biotechnol 2006;135:32-42.

20. Jha SK, Pasrija D, Sinha RK, Singh HR, Nigam VK, Vidyarthi AS. Microbial 1-asparaginase: A review on current scenario and future prospects. Int J Pharm Sci Res 2012;3:3076-90.

21. Sirisha B, Haritha. R. Efficacy the antiproliferative effect of 1-asparaginase from Streptomyces enissocaesilis on different tumour cell line. Indian J Curr Res Acad Rev 2017;5:95-102.

22. Poorani E, Saseethran MK, Dhevagi P. L-asparaginase production and molecular identification of marine Streptomyces sp strain EPD27. Int J Integr Biol 2009;7:150.

23. Hussain I, Sharma A, Kumar S, Malik F. Purification and characterization of glutaminase free 1-asparaginase from Enterobacter cloacae. In vitro evaluation of cytotoxic potential against human myeloid leukemia cell lines.Hl-60. J PLoS One 2016;18:21-6.

24. Khamna S, Yokota A, Lumyong S. Actinomycetes isolated from medicinal plant rhizosphere soils: Diversity and screening of antifungal compounds, indole 3 acetic acid and siderophore production. Int J Integr Biol 2009;6:22.

25. Bhat M, Marar T. Cytotoxic activity of purified 1-asparaginase from Salinicoccus species. Int J Curr Microbiol Appl Sci 2015;4:701-2.

26. Oza VP, Trivedi SD, Parmar PP, Subramanian RB. Withania somnifera (Ashwagantha): A novel source of l-asparaginase. J Integr Plant Biol 2009;51:201

27. Raha SK, Roy SK, Dey SK, Chakrabarty SL. Purification and properties of an L-asparaginase from Cylindrocarpon obtusisporum MB-10. Biochem Int 1990;21:987-1000.

28. Nguyen HA, Su Y, Lavie A. Design and characterization of Erwinia chrysanthemi 1-asparaginase variants with diminished 1-glutaminase activity. J Biol Chem 2016;291:17664-76.

29. Ommurugan B, Priya A, Bairy LK. A complete review of migraine. Asian Journal of Pharmaceutical and Clinical Research 2017;10:57-62.

30. Kumarai PV, Sankar GG, Prabakhar T. Optimization of 1-asparaginase production by Streptomyces griseoluteus WS3/1 using experimental methods. J Pharm Biomed Sci 2011;10:101-4.

31. Bell TL, Adams MA. Ecophysiology of ecto mycorrhizal fungi associated with Pinus spp. J Plant Ecol 2004;171:35-52.

32. Ebrahiminezhad A, Rasoul-Amini S, Ghasemi Y. L-asparaginase production by moderate halophilic bacteria isolated from maharloo salt lake. Indian J Microbiol 2011;51:307-11.

33. Naveena B, Narayani TG, Sakthiselvan P, Partha N. Antioxidant and antimicrobial efficacies of Amaranthus polygonoides and its impact on 1-asparaginase production. Afr J Biotechnol 2012;11:12483-90.

34. Dhevagi P, Poorani E. Isolation and characterization of 1-asparaginase from marine action mycetes. Indian J Biotechnol 2006;5:514.

35. Pradeep SM, Mahmood R, Jagadeesh KS. Screening and characterization of 1-asparaginase producing microorganisms from tulsi (Ocimum sanctum L.). Karnataka J Agric Sci 2010;2:394-660.

36. Patil N, Rao K, NaazH, Ommurugan B, Baiju G, Naik A, et al. Myxedema madness: An intriguing case of depression in hypothyroidism. Asian Journal of Pharmaceutical and Clinical Research 2017;10:8-9.

37. Ommurugan B, Bairy LK, Priya A, Thomas J, Patil N. A fatal case of bilateral interstitial pneumonia (Blip): Interferon alpha 2 a a inducced. Asian Journal of Pharmaceutical and Clinical Research 2017;10:15-6.

38. Gaffar SA, Shethna YI. Purification and some biological properties of asparaginase from Azotobacter vinelandii. Appl Environ Microbiol 1977;33:508-14. 